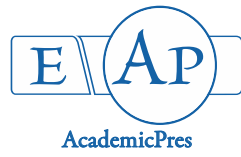

\title{
Economic Evaluation of Different Culture Enclosures for Musca domestica Larval Production and Their Utilization for Clarias gariepinus (Burchell, 1822) Fingerlings Diets
}

\author{
Asiata A. KOLAWOLE ${ }^{1 *}$, Adiaha Alda Alex UGWUMBA ${ }^{2}$ \\ ${ }^{1}$ Federal Unibersity of Kashere, Department of Biological Sciences, Gombe State, \\ Nigeria; asiatajimoh@yahoo.com ("corresponding author) \\ ${ }^{2}$ University of Ibadan, Hydrobiology and Fisheries Research Unit, Department of Zoology, Ibadan, Oyo State, Nigeria
}

\begin{abstract}
The study was designed to investigate the rate of larval (maggot) production from different culture enclosures, as well as to compare the cost effectiveness and utilization of the maggot in the diet of African mud catfish, Clarias gariepinus. Musca domestica larvae were cultured from poultry dung for five week, where upon they were utilized as a replacement for fish meal in the diet of fingerlings of African mud catfish. The maggots were cultured in four different enclosures: aluminium mobile maggotry, aluminium, plastic and wooden boxes. The harvested maggots were processed by oven drying and powdered as maggot meal. The maggot meal was used to substitute fish meal in eight diets with different inclusion levels of $0 \%$ (control), $20 \%, 30 \%, 40 \%, 50 \%, 60 \%, 70 \%$ and $80 \%$. The formulated diets were fed to C. gariepinus fingerlings in triplicates for 10 weeks. The growth, nutrient utilization and survival of fish were monitored during the experimental period. The cost effectiveness of different culture enclosure was studied. Results indicate that aluminium box was the best option, giving the highest weight of maggot production, and was the most cost effective of all the culture enclosures studied. Significant differences $(p<0.05)$ were recorded in weight gain of fish between the control and the maggot meal-based diets, while the highest weight gain was observed in fish fed $70 \%$ maggot meal-based diet. Specific and relative growth rates were found to be high in fish fed 60\% maggot meal diet, while they were lowest in fish fed $20 \%$ maggot meal diet and the control diet. The best protein intake was recorded in fish fed the 70\% maggot meal-based diet and lowest in fish fed the control diet. Survival of fish was generally high $(78.3 \%-93.30 \%)$ and was significantly $(\mathrm{p}<0.05)$ different between the fish fed as the control and the maggot meal-based diets. The study confirms that maggots of Musca domestica are suitable as partial replacement of fishmeal at 60-70\% inclusion level for optimal growth performance and nutrient utilization in Clarias gariepinus fingerlings.
\end{abstract}

Keywords: Clarias gariepinus; cost-effectiveness; culture enclosures; growth rate; larval production; nutrient utilization

\section{Introduction}

Fish is an important source of both food and income to many people in developing countries. Fish is the cheapest source of animal protein consumed by the average Nigerians, accounting for up to $50 \%$ of the total animal protein intake (Federal Department of Fisheries, 2007). Fish has been identified to be the solution to malnutrition due to its availability, general acceptance, nutritional quality and its relatively cheap price as a source of animal protein (Bene and Heck, 2002; Agbabiaka et al., 2012). According to FAO (2006), there is a huge supply-demand gap for fish and fishery products in Nigeria. However, the cost of feeding is a major limiting factor affecting the development of fish farms in Nigeria (Olomola, 1990).
The future growth of the aquaculture industry depends upon the availability of suitable and economical feeds. In 2015, the cost of imported fishmeal in Nigeria ranged between US\$2,800-3,050 per ton, while the cost of locally produced fishmeal was US\$ 1,270-1,550 per ton (Ezewudo et al., 2015). At present, around 10\% of global fish production goes to fishmeal (either whole fish or fish remains resulting from processing) and it is used mainly in aquaculture (FAO, 2012). The recent high demand and consequent high prices for fishmeal, together with increasing production pressure on aquaculture, has led to research on non-conventional animal proteins for aquaculture and livestock. Meanwhile, aquaculture is growing and fishmeal production is declining rapidly as a source of feed because of decreased supplies of caught fish $(\mathrm{FAO}, 2012)$ 
Musca domestica larvae (maggots) have shown to have great potential as an alternative supplement to fish meal in the diet of fish fingerlings (Ugwumba and Abumoye, 1998; Ugwumba et al., 2001; Sogbesan et al., 2005; Ogunji et al., 2006, 2008; Adenugba, 2012; Ezewudo et al., 2015). The culture of maggots is seen as converting wastes of low economic value, e.g. animal dung into valuable animal protein (Omoyinmi et al., 2005). In addition, the focus should also be on the benefits of maggots as fish feed.

The major problem with maggot production is harvesting/collection of the maggots from dung, hence, the need of aluminium mobile maggotry which makes harvesting/collection easier.

Adenugba (2012) compared the production of maggot from aluminium mobile maggotry which has a collection chamber at the base for easier collection of maggot with boxes namely: aluminium, plastic and wooden boxes. The author reported high production of maggots from aluminium mobile maggotry, but that plastic boxes were the most cost effective.

The present study was thus carried out to verify the production and cost effectiveness of maggot from aluminium mobile maggotry compared to different boxes (aluminium, plastic and wooden boxes) with the introduction of collection trays to each collection box to aid in the collection of the larva. In addition, the effect of replacement of fish meal with maggot meal in the diet of Clarias gariepinus fingerlings was studied.

\section{Materials and Methods}

\section{Larval production}

Maggots of the house fly (Musca domestica) were produced from fresh poultry dung which was collected from

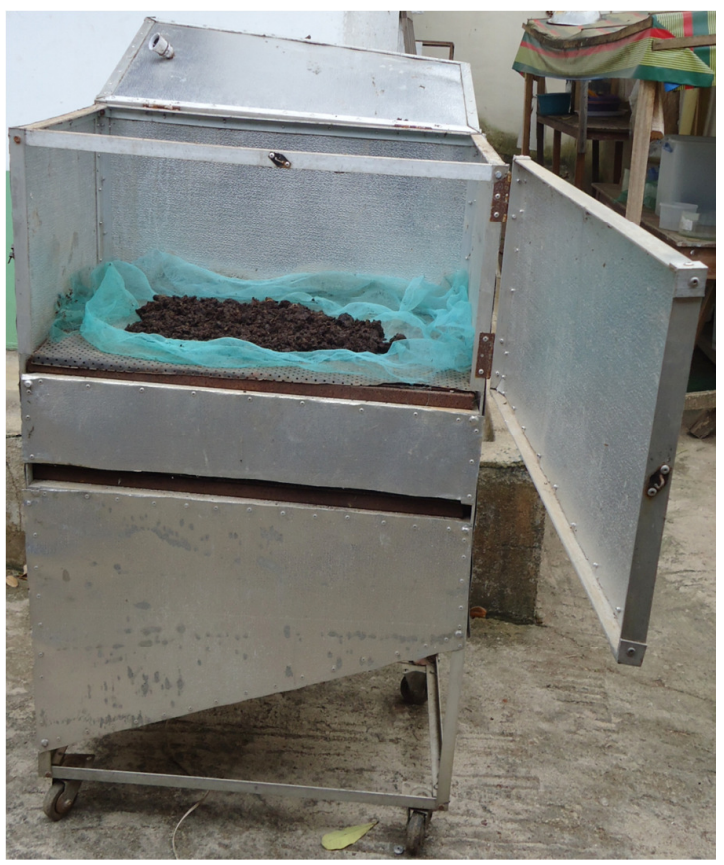

Fig. 1. Aluminium mobile maggotry used for production of maggots
Oluwalonse Farm, Lanniba Village, Ajibode, Ibadan, using four culture enclosures namely: aluminium mobile maggotry, as well as aluminium, wooden and plastic boxes.

\section{Aluminium mobile maggotry}

The aluminium mobile maggotry $(1.2 \times 0.8 \times 0.5 \mathrm{~m})$ was made with aluminium and consisted of three chambers: top, middle and bottom. The top chamber of the maggotry was the culture chamber. It had a lid at the top and at the side of the chamber for easy introduction of the culture substrate. The base of the culture chamber was screened with $3 \mathrm{~mm}$ wire mesh net to allow dropping of maggot. Mosquito (1.8 mm mesh size) net was put on the wire mesh to allow dropping of the maggots with less dung. The middle chamber was the cleaning chamber for maggots emerging from the culture chamber. The base of this chamber was also screened with $3 \mathrm{~mm}$ mesh size, which aided in the cleaning of maggots from the remains of the culture substrate. The bottom chamber was the collection chamber where the maggots were collected. It has an outlet at the side (Fig. 1).

\section{Culture boxes}

The aluminium boxes that were used for the maggot production each measured $0.2 \times 0.33 \times 0.5 \mathrm{~m}$; plastic boxes measured $0.5 \times 0.35 \times 0.22 \mathrm{~m}$ and the wooden boxes each measured $0.6 \times 0.5 \times 0.3 \mathrm{~m}$ (Figs. 2, 3, 4). The boxes were perforated on all sides with open top. The side perforations were to allow adequate aeration, while the perforations underneath the boxes were to allow dropping of maggots. A tray painted black was put under each box to allow for easy collection of maggots. The bottom of the boxes was lined inside with mosquito nettings to reduce the amount of dung dropping with the maggot. All the culture boxes were placed on a constructed long wooden table.

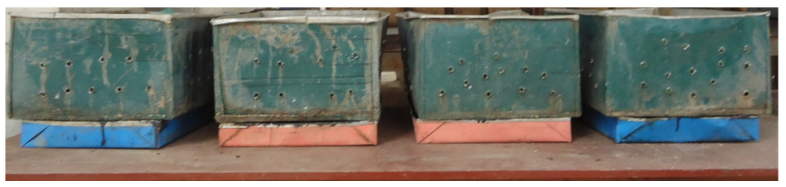

Fig. 2. Aluminium boxes used for production of maggots

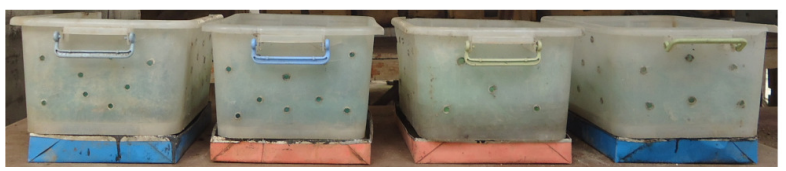

Fig. 3. Plastic boxes used for production of maggots

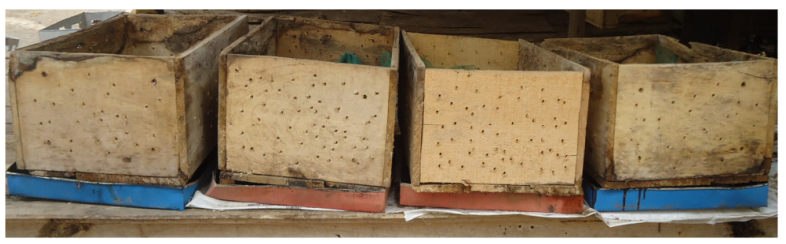

Fig. 4. Wooden boxes used for production of maggots 
468

\section{Experimental procedure for larval production}

Ten kilograms of freshly collected dung which were placed in air tight sacks in order to kill any maggots were placed in each maggotry and each box. The culture enclosures were in quadruplicates. The dung in each culture enclosures were exposed to flies for egg-laying for three days. Water was sprinkled to wet the dung each day, to enhance maggot production from the dung and prevent them from drying up. The set up was checked every day in order to harvest maggots for 5 weeks.

\section{Harvesting of larvae}

Harvesting of larvae (maggots) started on the fourth day of exposure of poultry dung to fly. The early instar of maggots is 3 to $9 \mathrm{~mm}$ long, typically creamy whitish in colour. The larvae go through three instars and a full-grown maggot, of 7 to $12 \mathrm{~mm}$ long, has a greasy, creamed coloured appearance. Maggots that emerged from the substrates were harvested daily. Harvesting of maggot from the mobile maggotry was done by collecting the maggots from the outlet of the maggotry, while those from the boxes were harvested by lifting the boxes and collecting the maggots in the tray beneath the boxes. The boxes were replaced on the trays after the maggots were collected. The dung was disposed of after a week, and fresh dung was collected and exposed to flies. This process was repeated for 5 weeks.

\section{Processing oflarva}

Harvested maggots were rinsed with water to remove traces of dung on them. The maggots were drained and weighed. The maggots were then blanched with hot water, and poured on a sieve to drain off water and weighed again. The maggots were then oven-dried at $105^{\circ} \mathrm{C}$ for $24 \mathrm{hrs}$, cooled and grounded into maggot meal using a blending machine. The maggots were then analysed for proximate composition as shown in Table 1 below. The maggot meal was packed in an air-tight plastic container and stored in a refrigerator till when needed.

\section{Feeding trial with C. gariepinus}

\section{Formulation and preparation of experimental diets}

The experimental diets consisted of eight isonitrogenous diets of $40 \%$ crude protein with the fish meal component replaced with maggot meal at $0 \%$ Diet A (control), 20\%, Diet B; 30\%, Diet C; 40\%, Diet D; 50\%, Diet E; 60\%, Diet F; 70\%, Diet G and 80\%, Diet H. Fish meal, corn meal, mineral and vitamins premix used in compounding the diets were purchased from Kesmac, Orogun, Ibadan, while cassava starch (used as binder) and soybean oil were purchased from Bodija Market, Ibadan. The gross and proximate composition of each diet is shown in Table 2.

The appropriate amounts of ingredients in each diet were weighed and thoroughly mixed manually in a bowl to ensure uniformity of ingredients; cassava starch prepared with hot water into a paste was then added to bind the ingredients. The feeds were sun-dried till properly dried with no traces of moisture.

The dried feed were packed in air-tight plastic containers and stored at room temperature in the laboratory.

Table 1. Proximate composition of harvested maggot meal

\begin{tabular}{cc}
\hline Nutrient & Percentage (\%) \\
\hline Crude protein (\%) & 45.50 \\
Crude Lipid (\%) & 9.00 \\
Crude fibre (\%) & 3.00 \\
Ash (\%) & 12.00 \\
\hline
\end{tabular}

Table 2. Gross and proximate composition of experimental diets

\begin{tabular}{ccccccccc}
\hline \multirow{2}{*}{ Ingredients } & \multicolumn{9}{c}{ Diets } \\
\cline { 2 - 9 } & Diet A & Diet B & Diet C & Diet D & Diet E & Diet F & Diet G & Diet H \\
\hline Fish meal (g) & 44.88 & 39.04 & 35.88 & 32.09 & 28.10 & 23.69 & 18.75 & 13.24 \\
Maggot meal (g) & - & 9.77 & 15.38 & 21.39 & 28.10 & 35.50 & 43.74 & 52.96 \\
\hline Corn meal (g) & 45.12 & 41.19 & 38.74 & 36.51 & 33.80 & 30.83 & 27.51 & 23.81 \\
*Vitamin \& Mineral premix (g) & 0.50 & 0.50 & 0.50 & 0.50 & 0.50 & 0.50 & 0.50 & 0.50 \\
Soybean oil (g) & 1.50 & 1.50 & 1.50 & 1.50 & 1.50 & 1.50 & 1.50 & 1.50 \\
Cassava starch binder (g) & 8.00 & 8.00 & 8.00 & 8.00 & 8.00 & 8.00 & 8.00 & 8.00 \\
Total (g) & 100 & 100 & 100 & 100 & 100 & 100 & 100 & 100 \\
Calculated crude protein (\%) & 40 & 40 & 40 & 40 & 40 & 40 & 40 & 40 \\
Inclusion levels of maggot meal (\%) & $0 \%$ & $20 \%$ & $30 \%$ & $40 \%$ & $50 \%$ & $60 \%$ & $70 \%$ & $80 \%$ \\
Crude protein(\%) & $38.55 \pm 1.23^{\mathrm{a}}$ & $38.25 \pm 1.00^{\mathrm{a}}$ & $38.21 \pm 1.31^{\mathrm{a}}$ & $38.50 \pm 1.05^{\mathrm{a}}$ & $38.35 \pm 1.02^{\mathrm{a}}$ & $38.38 \pm 1.25^{\mathrm{a}}$ & $38.43 \pm 1.25^{\mathrm{a}}$ & $38.52 \pm 1.15^{\mathrm{a}}$ \\
Crude lipid (\%) & $7.00 \pm 2.00^{\mathrm{a}}$ & $7.08 \pm 2.00^{\mathrm{a}}$ & $8.00 \pm 1.00^{\mathrm{a}}$ & $7.50 \pm 1.50^{\mathrm{a}}$ & $7.50 \pm 1.00^{\mathrm{a}}$ & $7.53 \pm 1.25^{\mathrm{a}}$ & $8.00 \pm 2.00^{\mathrm{a}}$ & $7.00 \pm 2.00^{\mathrm{a}}$ \\
\hline Crude fibre (\%) & $3.00 \pm 0.50^{\mathrm{a}}$ & $3.50 \pm 1.50^{\mathrm{a}}$ & $4.00 \pm 1.00^{\mathrm{a}}$ & $3.50 \pm 1.00^{\mathrm{a}}$ & $3.00 \pm 1.00^{\mathrm{a}}$ & $4.00 \pm 1.00^{\mathrm{a}}$ & $4.00 \pm 1.40^{\mathrm{a}}$ & $3.50 \pm 1.40^{\mathrm{a}}$ \\
Crude ash (\%) & $7.00 \pm 1.00^{\mathrm{a}}$ & $9.00 \pm 1.50^{\mathrm{a}}$ & $8.00 \pm 1.50^{\mathrm{a}}$ & $13.00 \pm 1.00^{\mathrm{bc}}$ & $9.00 \pm 2.00^{\mathrm{a}}$ & $8.00 \pm 1.00^{\mathrm{a}}$ & $14.00 \pm 2.00^{\mathrm{c}}$ & $10.00 \pm 1.00^{\mathrm{ab}}$ \\
Dry matter (\%) & $89.81 \pm 1.54^{\mathrm{a}}$ & $90.07 \pm 1.18^{\mathrm{a}}$ & $89.75 \pm 0.94^{\mathrm{a}}$ & $89.52 \pm 1.00^{\mathrm{a}}$ & $89.28 \pm 1.53^{\mathrm{a}}$ & $90.21 \pm 1.15^{\mathrm{a}}$ & $89.30 \pm 1.05^{\mathrm{a}}$ & $88.81 \pm 1.31^{\mathrm{a}}$ \\
\hline
\end{tabular}

Vitamins and Minerals premix: $1 \mathrm{~kg}$ of premix contains: Vitamin A- 12,500,000.00 I.U, Vitamin D3-2,500,000.00 I.U, Vitamin E- 40,000.00 mg, Vitamin K3- 2,000.00 mg, Vitamin B1- 3,000.00 mg, Vitamin B2- 5,500.00 mg, Niacin- 55,000.00 mg, Calcium pantothenate- 11,500.00 mg, Vitamin B6- 5,000.00 mg, Vitamin B12- 25.00 mg, Folic acid- 1,000 mg, Choline chloride- 500,000.00 mg, Biotin- $80.0 \mathrm{mg}$, Manganese- 120,000.00 mg, Iron- 100,000.00 mg, Zinc- 80,000.00 mg, Copper- 8,500.00 $\mathrm{mg}$, Iodine- $1,500.00 \mathrm{mg}$, Cobalt- $300.00 \mathrm{mg}$, Selenium- $120.00 \mathrm{mg}$, Anti-oxidant- $120,000.00 \mathrm{mg}$.

Values on the same row with different superscript are significantly different $(\mathrm{p}<0.05)$. 
Proximate composition of the experimental diets for crude protein, crude lipid, crude fibre, crude ash and dry matter were determined using AOAC method AOAC, (2012).

\section{Experimental procedure}

Five hundred and fifty fingerlings of Clarias gariepinus mean weight $(1.45 \mathrm{~g} \pm 0.19 \mathrm{~g})$ were purchased from AKAM Farm, Ibadan.

The fingerlings were acclimatized in the laboratory for one week, fed with Coppens feed of $0.8 \mathrm{~mm}$ and starved for 24 hours before the commencement of the feeding trial. Fingerlings of known sizes were stocked into each tank at a stocking density of 20 fingerlings per tank, making 60 fingerling per experimental diet.

The tanks were checked daily for mortality; dead fish were removed, counted and the number was recorded.

The fingerlings were fed manually by broadcasting at 5\% body weight in two equal rations daily, in the morning $(09.00 \mathrm{~h})$ and evening $(19.00 \mathrm{~h})$ for ten weeks. The rations were adjusted weekly based on the sampled total weight of fish in each tank. The behavior of the fingerlings was observed during feeding.

The lengths and weights of each fingerling in each tank were measured at the beginning of the experiment. Total and average lengths and weights per tank and per diet were calculated and recorded as initial lengths and weights.

Five fingerlings were sampled randomly from each tank weekly to determine the growth rate and review the feed rations. The fingerlings were quickly weighed and returned back into the tank; the average and total weights per tank and diet were calculated.

At the end of the experiments the final lengths and weights of all fish left in each tank were measured. Average and total weights were computed.

\section{Economic analysis of diets formulated}

The economic evaluation of the diets formulated was calculated using the formulae reported in Sogbesan et al. (2006):

Estimated Investment Cost Analysis $=$ Cost of feed $(\$)$ + Cost of Fingerlings (\$)

Profit Index $=$ Value of Fish $(\$) /$ Cost of Feed $(\$)$ (\$)

Net Profit $=$ Total Cost of Fish $(\$)-$ Total Expenditure

Incident Cost $=$ Cost of Feed (\$) / Mean Weight Gain of Fish $(\mathrm{g})$

Cost: Benefit Ratio (C:Br) = Total Cost of Fish Cropped (\$)/Total Expenditure (\$)

\section{Determination of water quality parameters}

The physico-chemical parameters that was determined throughout the experimental period were temperature which was taken daily between the hour of 08.00-09.00 while $\mathrm{pH}$ and dissolved oxygen were determined once a week.

The temperature was determined using a mecury-inglass thermometer, while the dissolved oxygen was determined using Winkler's titrimetric method described by Boyd (1990). A Jenway 3510npH meter was used to determine the $\mathrm{pH}$.
Determination of growth and nutrient utilization of fish

Growth, nutrient utilization and survival parameters were computed for fingerlings on each diet using the formulae in Monebi and Ugwumba (2013):

Mean Length Gain = FML - IML

Where FML is the final mean length ( $\mathrm{cm} /$ fish)

IML is the initial mean length $(\mathrm{cm} /$ fish)

Mean Weight Gain = FMW- IMW

Where FMW is the final mean weight $(\mathrm{g} /$ fish $)$

IMW is the initial mean weight $(\mathrm{g} / \mathrm{fish})$

Relative Growth Rate $(\mathrm{RGR}) \%=\left(\mathrm{W}_{\mathrm{f}}-\mathrm{W}_{\mathrm{i}} / \mathrm{W}_{\mathrm{i}}\right) \times 100$

Where $\mathrm{W}_{\mathrm{i}}$ is the initial weight of fish

$\mathrm{W}_{\mathrm{f}}$ is the final weight of fish.

Specific Growth Rate $(\mathrm{SGR}) \%=\left(\operatorname{loge} \mathrm{W}_{\mathrm{f}}-\operatorname{loge}_{\mathrm{i}}\right.$ $/ \mathrm{T}) \times 100$

Where $\operatorname{loge} \mathrm{W}_{\mathrm{i}}$ is the natural logarithm of initial weight of fish and

$\operatorname{logeW}_{\mathrm{f}}$ is the natural logarithm of final weight of fish

$T$ is the total number of days of experiment.

Food Conversion Ratio (FCR) \% = Total food supplied (g)/ Total weight gain (g) feed

Protein Intake $=$ Food supplied $(\mathrm{g}) \times \%$ crude protein of

Protein Efficiency Ratio (PER)\% = Mean weight gain $(\mathrm{g}) /$ Mean protein intake

Protein Productive Value $(\mathrm{PPV}) \%=\left\{\left(\mathrm{BP}_{1}-\mathrm{BP}_{0}\right) / \mathrm{PI}\right\} \mathrm{x}$ 100.

Where: $\mathrm{BP}_{0}$ : Initial body protein content (g); $\mathrm{BP}_{1}$ : Final body protein content $(\mathrm{g})$; PI: Protein intake $(\mathrm{g})$

Survival $(S)=\left(\underline{N_{f}} / N_{i}\right) \times 100$

Where $\mathrm{N}_{\mathrm{i}}=$ Number of fish at the beginning of the experiment.

$\mathrm{N}_{\mathrm{f}}=$ Number of cultured fish at the end of the experiment

\section{Statistical analysis}

All the data were subjected to descriptive statistics and one-way Analysis of Variance (ANOVA) using a computer software (SPSS 16.00 version). A probability value of 0.05 was used as bench mark for significant difference between parameters.

\section{Results}

\section{Production of larvae}

The maggots emerged from the fourth day of exposure. The production from each enclosure increased gradually from the fourth day of exposure and decreased on the seventh day of each week. The aluminium culture box had the highest weekly weight of $320.54 \mathrm{~g}$ maggot $/ 10 \mathrm{~kg}$ dung/week of maggot produced, while the aluminium mobile maggotry had the lowest production of $45.06 \mathrm{~g}$ maggot $/ 10 \mathrm{~kg}$ dung/ week (Fig. 5). There was a significant difference $(\mathrm{p}<0.05)$ between the mean weights of maggots produced in all the four culture enclosures. Aluminium box was found to be most cost-effective $\$ 0.006 / 10 \mathrm{~kg}$ maggot while aluminium mobile maggotry was the least cost effective with $\$ 0.218 / 10 \mathrm{~kg}$ maggot (Table 3 ). There was a significant difference $(\mathrm{p}<0.05)$ in the cost-effectiveness of the four culture enclosures. 
470

\section{Feeding trial with C. gariepinus}

There was a progressive increase in the growth of the fingerlings on all the diets throughout the experimental period. Mean weight gain was the highest in fish fed with the $70 \%$ maggot meal diet and the lowest in fish fed the control diet (Fig. 6). There was a significant difference ( $\mathrm{p}<$ 0.05 ) between the mean weight gain of fingerlings fed with the control diet and all the maggot-based diets.

Relative and specific growth rates were also highest $(1,261.79 \%$ and $1.61 \%)$ in fish fed $60 \%$ maggot meal diet and lowest $(637.72 \%$ and $1.24 \%)$ in fish fed with the control diet (Table 4). There were significant differences ( $\mathrm{p}$ $<0.05$ ) between the relative and specific growth rates of fish fed control diet and all the maggot-based diets.

Food Conversion Ratio (FCR) was the highest in fish fed with the control diet (2.36), while those fed with 60\% maggot meal diet had the lowest FCR of 1.93 and these were significantly different $(\mathrm{p}<0.05)$. Fish fed with $70 \%$ maggot meal diet had the highest protein intake (16.48), while the lowest value (9.17) was recorded in fish fed with control diet and the values were also significantly different $(\mathrm{p}<0.05)$.

Protein efficiency ratio was the lowest in fish fed with $40 \%$ maggot meal diet (1.00) and the highest (1.13) in fish fed with $60 \%$ maggot meal diet. There was no significant difference in the Protein Efficiency Ratio (PER) of fish on all the experimental diets. Highest Protein Productive Value (PPV)(34.89) was recorded in fishes fed 70\% maggot meal diet, while the lowest (7.63) was in fish with control diet.

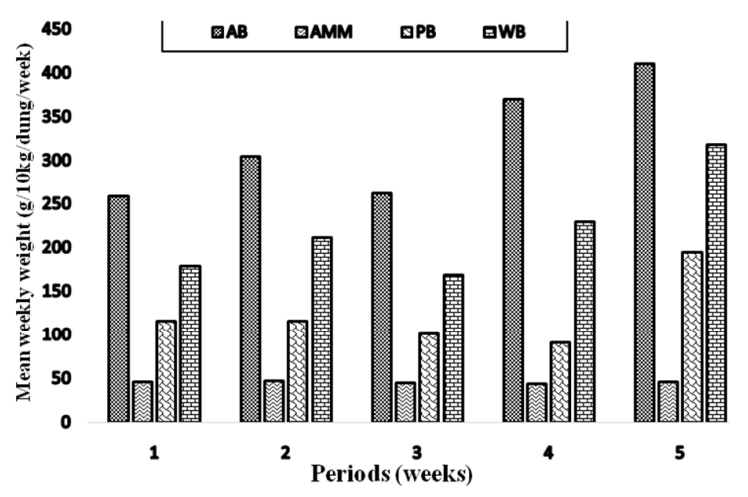

Fig. 5. Mean weekly weight of maggot produced from various enclosures

$\mathrm{AB}=$ Aluminium box; $\mathrm{AMM}=$ Aluminium mobile maggotry; $\mathrm{PB}=$ Plastic box; WB = Wooden box
The PPV value was significantly different $(\mathrm{p}<0.05)$ between the control and maggot meal-based diets.

The proximate composition of fish carcass before and after the experiment is shown in Table 5 . The crude protein, crude lipid and ash content of the fish carcass before the experiment were $71.75 \%, 7.75 \%$ and $12.33 \%$ respectively; at the end of the experiment, the value of crude protein ranged from $72.45-75.50 \%$, with $70 \%$ maggot meal based diet having the highest value, crude lipid 7.50-8.00 and ash content 12.00-13.00.

\section{Economic analysis of diets formulated}

The economic evaluation of the diets formulated is shown in Table 6. At the end of the experiment, the best net profit of $\$ 12.24$ and cost:benefit ratio of 3.38 was recorded from fish fed $60 \%$ maggot meal-based diet, while the lowest net profit and cost:with ratio value of $\$ 1.80$ and 1.92 was recorded with control diet.

\section{Discussion}

The four enclosures used were suitable for production of maggots. However, the best maggot production came from the aluminium culture box which was also the most cost effective, compared to other culture enclosures.

These results are contrary to those of Adenugba (2012) who reported that the aluminium mobile maggotry yielded the highest production of maggots, while the plastic culture box was the most cost effective.

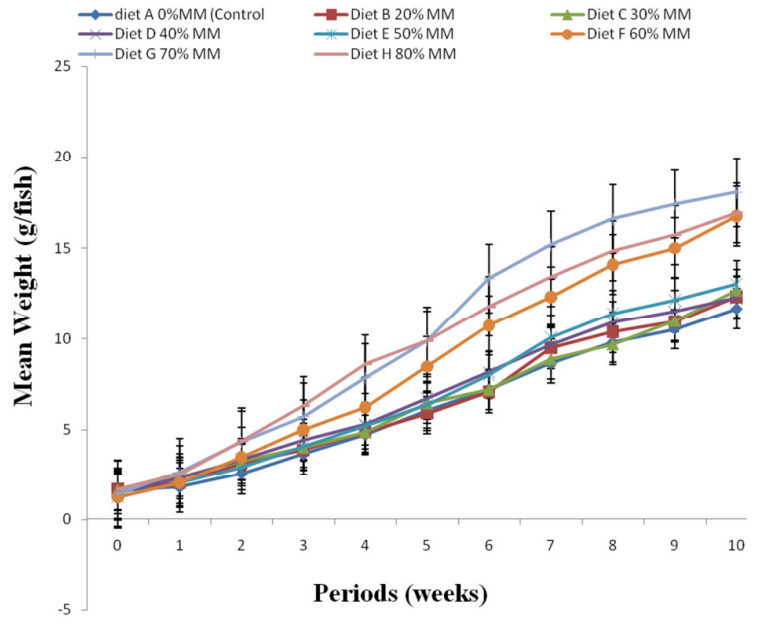

Fig. 6. Weekly weight changes of Clarias gariepinus fingerlings fed the various experimental diets

Table 3. Cost of maggot production from the various culture enclosures

\begin{tabular}{cccc}
\hline Enclosure & Cost of enclosures $(\$)$ & Amount of maggot produced $(\mathrm{g} / 10 \mathrm{~kg}$ dung $/$ week $)$ & $\begin{array}{c}\text { Incidence cost } \\
(\$ / 10 \mathrm{~kg} \text { dung })\end{array}$ \\
\hline Mobile maggotry & 9.81 & 45.06 & 0.218 \\
Aluminium box & 1.87 & 320.54 & 0.006 \\
Plastic box & 1.33 & 123.24 & 0.011 \\
Wooden box & 2.67 & 220.84 & 0.012 \\
\hline
\end{tabular}


Table 4. Growth and nutrient utilization of Clarias gariepinus fed with various diets

\begin{tabular}{|c|c|c|c|c|c|c|c|c|}
\hline Parameters & $\begin{array}{c}\text { Diet A 0\% MM } \\
\text { (Control) }\end{array}$ & $\begin{array}{c}\text { Diet B 20\% } \\
\text { MM }\end{array}$ & $\begin{array}{c}\text { Diet C 30\% } \\
\text { MM }\end{array}$ & $\begin{array}{c}\text { Diet D 40\% } \\
\text { MM }\end{array}$ & $\begin{array}{c}\text { Diet } \mathrm{E} 50 \% \\
\text { MM }\end{array}$ & $\begin{array}{c}\text { Diet F } 60 \% \\
\text { MM }\end{array}$ & $\begin{array}{c}\text { Diet G 70\% } \\
\text { MM }\end{array}$ & $\begin{array}{c}\text { Diet H } 80 \% \\
\text { MM }\end{array}$ \\
\hline IML (cm/fish) & $5.83 \pm 0.321^{b}$ & $5.77 \pm 0.289^{b}$ & $5.83 \pm 0.208^{b}$ & $5.83 \pm 0.115^{b}$ & $5.43 \pm 0.321^{\mathrm{ab}}$ & $5.230 .058^{\mathrm{a}}$ & $5.87 \pm 0.231^{b}$ & $5.63 \pm 0.115^{\mathrm{ab}}$ \\
\hline FML (cm/fish) & $11.42 \pm 0.448^{2}$ & $11.23 \pm 0.427^{\mathrm{a}}$ & $12.23 \pm 0.075^{a}$ & $11.72 \pm 0.831^{a}$ & $11.89 \pm 0.638^{\mathrm{a}}$ & $12.100 .594^{\mathrm{a}}$ & $14.39 \pm 0.507^{b}$ & $14.12 \pm 0.429^{\mathrm{b}}$ \\
\hline MLG (cm/fish) & $5.59^{\mathrm{ab}}$ & $5.46^{a}$ & $6.40^{c}$ & $5.89^{b}$ & $6.46^{c}$ & $6.87^{\mathrm{d}}$ & $8.52^{\mathrm{e}}$ & $8.49^{\circ}$ \\
\hline IMW (g/fish) & $1.57 \pm 0.058^{\mathrm{ab}}$ & $1.67 \pm 0.289^{b}$ & $1.63 \pm 0.115^{b}$ & $1.47 \pm 0.282^{\mathrm{ab}}$ & $1.23 \pm 0.153^{\mathrm{a}}$ & $1.23 \pm 0.115^{a}$ & $1.40 \pm 0.173^{\mathrm{ab}}$ & $1.67 \pm 0.153^{b}$ \\
\hline FMW (g/fish) & $11.67 \pm 1.563^{\mathrm{a}}$ & $12.32 \pm 2.385^{a}$ & $12.70 \pm 3.310^{a}$ & $12.26 \pm 0.947^{\mathrm{a}}$ & $13.02 \pm 2.378^{a}$ & $16.73 \pm 4.347^{a}$ & $18.05 \pm 2.444^{2}$ & $16.924 .489^{\mathrm{a}}$ \\
\hline MWG (g/fish) & $10.10 \pm 0.345^{a}$ & $10.65 \pm 0.214^{\mathrm{ab}}$ & $11.07 \pm 0.315^{b}$ & $10.79 \pm 0.411^{\mathrm{b}}$ & $11.80 \pm 0.359^{c}$ & $15.52 \pm 0.174^{\mathrm{d}}$ & $16.65 \pm 0.410^{\mathrm{e}}$ & $15.25 \pm 0.500^{d}$ \\
\hline RGR (\%) & $643.31 \pm 0.231^{b}$ & $637.72 \pm 0.341^{a}$ & $679.14 \pm 0.233^{c}$ & $734.01 \pm 0.491^{\mathrm{d}}$ & $959.35 \pm 0.372^{f}$ & $1,261.79 \pm 0.431^{\mathrm{h}}$ & $1,189.29 \pm 0.412^{g}$ & $913.17 \pm 0.315^{\mathrm{e}}$ \\
\hline SGR (\%) & $1.24 \pm 0.193^{a}$ & $1.24 \pm 0.211^{a}$ & $1.27 \pm 0.274^{\mathrm{ab}}$ & $1.31 \pm 0.352^{\mathrm{ab}}$ & $1.46 \mathrm{~b} \pm 0.364^{\mathrm{c}}$ & $1.61 \pm 0.152^{c}$ & $1.59 \pm 0.234^{c}$ & $1.44 \pm 0.233^{\mathrm{abc}}$ \\
\hline FCR & $2.36 \pm 0.121^{d}$ & $2.22 \pm 0.014^{c}$ & $2.13 \pm 0.110^{\mathrm{bc}}$ & $2.34 \pm 0.109^{d}$ & $2.08 \pm 0.037^{\mathrm{b}}$ & $1.93 \pm 0.191^{a}$ & $2.13 \pm 0.162 b^{c}$ & $2.16 \pm 0.171^{b c}$ \\
\hline PI & $9.17 \pm 0.213^{\mathrm{a}}$ & $10.19 \pm 0.210^{\mathrm{ab}}$ & $10.04 \pm 0.315^{\mathrm{ab}}$ & $10.82 \pm 0.312^{b}$ & $10.70 \pm 0.109^{\mathrm{ab}}$ & $13.70 \pm 0.320^{c}$ & $16.48 \pm 0.261^{d}$ & $15.04 \pm 0.321^{\mathrm{cd}}$ \\
\hline PER & $1.10 \pm 0.302^{\mathrm{a}}$ & $1.05 \pm 0.219^{a}$ & $1.10 \pm 0.331^{\mathrm{a}}$ & $1.00 \pm 0.219^{\mathrm{a}}$ & $1.10 \pm 0.261^{a}$ & $1.13 \pm 0.304^{\mathrm{a}}$ & $1.01 \pm 0.341^{a}$ & $1.01 \pm 0.293^{\mathrm{a}}$ \\
\hline PPV & $7.63 \pm 0.218^{\mathrm{a}}$ & $14.82 \pm 0.329^{d}$ & $21.12 \pm 0.274^{c}$ & $25.51 \pm 0.352^{d}$ & $32.99 \pm 0.319^{f}$ & $29.12 \pm 0.193^{e}$ & $34.89 \pm 0.410^{\mathrm{g}}$ & $31.45 \pm 0.391^{\mathrm{f}}$ \\
\hline Survival (\%) & $78.30 \pm 0.521^{a}$ & $93.3 \pm 0.428^{d}$ & $86.7 \pm 0.602^{\mathrm{bc}}$ & $85.0 \pm 0.319^{b}$ & $88.3 \pm 0.592^{c}$ & $91.7 \pm 0.721^{\mathrm{d}}$ & $91.7 \pm 0.683^{d}$ & $93.3 \pm 0.739^{d}$ \\
\hline
\end{tabular}

Values with different superscripts on the same row are significantly different $(\mathrm{p}<0.05)$. Key: MM = Maggot meal; IMW = Initial Mean Weight; FMW = Final Mean Weight; MWG = Mean Weight Gain; RGR = Relative Growth Rate; SGR = Specific Growth Rate; FCR = Food Conversion Ratio; PI = Protein Intake; PER = Protein Efficiency Ratio; PPV = Protein Productive Value.

Table 5. Carcass composition of experimental fish fed the different diets at the beginning and end of feeding trials (\% dry weight)

\begin{tabular}{|c|c|c|c|c|c|c|c|c|c|}
\hline \multirow[b]{2}{*}{$\begin{array}{c}\text { Compositi } \\
\text { on }\end{array}$} & \multirow[b]{2}{*}{$\begin{array}{l}\text { Initial } \\
\text { carcass }\end{array}$} & \multicolumn{8}{|c|}{ Final carcass } \\
\hline & & $\begin{array}{c}0 \% \mathrm{MM} \\
\text { (Control) }\end{array}$ & $20 \% \mathrm{MM}$ & $30 \% \mathrm{MM}$ & $40 \% \mathrm{MM}$ & $50 \% \mathrm{MM}$ & $60 \% \mathrm{MM}$ & $70 \% \mathrm{MM}$ & $80 \% \mathrm{MM}$ \\
\hline $\begin{array}{c}\text { Crude } \\
\text { protein (\%) }\end{array}$ & $71.75 \pm 0.95^{\mathrm{a}}$ & $72.45 \pm 1.22^{b}$ & $73.26 \pm 2.26^{\mathrm{ab}}$ & $73.87 \pm 1.07^{\mathrm{abc}}$ & $\begin{array}{c}74.51 \pm 0.30^{\mathrm{abc}} \\
\mathrm{d}\end{array}$ & $75.28 \pm 7.08^{\text {bcde }}$ & $75.74 \pm 1.50^{\text {cde }}$ & $77.50 \pm 0.50^{\mathrm{e}}$ & $76.48 \pm 0.40^{\mathrm{de}}$ \\
\hline $\begin{array}{c}\text { Crude lipid } \\
(\%)\end{array}$ & $7.75 \pm 0.35^{a}$ & $8.00 \pm 0.98^{\mathrm{a}}$ & $7.50 \pm 0.30^{\mathrm{a}}$ & $7.50 \pm 0.3^{\mathrm{a}}$ & $8.00 \pm 0.70^{a}$ & $7.50 \pm 0.40^{\mathrm{a}}$ & $7.50 \pm 0.40^{\mathrm{a}}$ & $7.50 \pm 0.60^{a}$ & $8.00 \pm 0.80^{\mathrm{a}}$ \\
\hline Ash (\%) & $12.33 \pm 1.23^{a b}$ & $12.00 \pm 0.97^{\mathrm{ab}}$ & $14.00 \pm 0.17^{\mathrm{b}}$ & $14.00 \pm 0.98^{b}$ & $11.00 \pm 0.70^{a}$ & $13.00 \pm 1.20^{\mathrm{ab}}$ & $13.00 \pm 1.20^{\mathrm{ab}}$ & $13.00 \pm 0.90^{\mathrm{ab}}$ & $12.00 \pm 0.70^{\mathrm{ab}}$ \\
\hline $\begin{array}{c}\text { Crude fibre } \\
(\%)\end{array}$ & $1.80 \pm 0.20^{\mathrm{a}}$ & $2.00 \pm 0.20^{\mathrm{b}}$ & $2.10 \pm 0.2^{\mathrm{b}}$ & $2.30 \pm 0.3^{b}$ & $2.00 \pm 0.1^{\mathrm{b}}$ & $2.20 \pm 0.3^{\mathrm{b}}$ & $2.00 \pm 0.3^{\mathrm{b}}$ & $2.30 \pm 0.2^{\mathrm{b}}$ & $2.00 \pm 0.10^{\mathrm{b}}$ \\
\hline $\begin{array}{c}{ }^{*} \text { Dry } \\
\text { matter }(\%)\end{array}$ & $22.76 \pm 1.50^{\mathrm{bc}}$ & $22.24 \pm 1.86^{\mathrm{ab}}$ & $23.34 \pm 1.10^{\mathrm{bc}}$ & $27.63 \pm 1.10^{\mathrm{ab}}$ & $24.66 \pm 0.50^{c}$ & $20.80 \pm 0.77^{\mathrm{a}}$ & $21.93 \pm 0.40^{\mathrm{ab}}$ & $22.00 \pm 0.80^{\mathrm{ab}}$ & $22.16 \pm 0.16^{\mathrm{ab}}$ \\
\hline $\begin{array}{l}{ }^{*} \text { Moisture } \\
\text { content }(\%)\end{array}$ & $76.00 \pm 0.65^{\mathrm{ab}}$ & $75.8 \pm 1.08^{\mathrm{a}}$ & $76.66 \pm 1.06^{\mathrm{abc}}$ & $78.37 \pm 1.00^{\mathrm{cd}}$ & $75.34 \pm 1.14^{a}$ & $79.20 \pm 0.20^{\mathrm{d}}$ & $78.07 \pm 1.07^{\mathrm{cd}}$ & $78.00 \pm 1.00^{\mathrm{cd}}$ & $\begin{array}{c}77.84 \pm 1.34^{c} \\
\mathrm{~d}\end{array}$ \\
\hline
\end{tabular}

Table 6. Economic analysis of diets formulated

\begin{tabular}{cccccc}
\hline Diet & E. I. C. A. $(\$)$ & Profit index $(\$)$ & Net profit $(\$)$ & Incident of cost & Cost:Benefit ratio \\
\hline A & 1.96 & 0.01 & 1.80 & 0.72 & 1.07 \\
B & 2.73 & 0.01 & 4.84 & 1.25 & 2.84 \\
C & 3.02 & 0.01 & 6.00 & 1.63 & 2.97 \\
D & 3.61 & 0.01 & 7.27 & 1.70 & 3.01 \\
E & 4.01 & 0.01 & 8.01 & 1.84 & 3.00 \\
F & 5.36 & 0.01 & 12.24 & 3.36 & 3.28 \\
G & 7.08 & 0.01 & 9.06 & 2.78 & 1.97 \\
H & 7.58 & 0.01 & 7.36 & & \\
\hline
\end{tabular}

Estimated investment cost analysis

This could be due to the fact that the present study introduced collection of trays for harvesting maggots from the culture boxes which made harvesting of maggot easier. The inner part of the tray was painted black as it is known that maggots like dark places and are negatively phototactic. The collection trays made harvesting easier and reduce loss of maggots which Adenugba did not use.

The crude protein content of maggot meal $(45.50 \%)$ from the present study was higher than that of Ogunji et al. (2006) (38.90), compares well with that reported by
Ezewudo et al. (2015) (45.50\%) and was similar with that reported by Gado et al. (1982) (45.0\%), Atteh and Olegbenla (1993) (45.0\%), while it was close to those reported by Ugwumba et al. (2001) (41.3\%) and Okah and Onwujiariri (2012) (44.44\%), but at variance with those of Calvert et al. (1976) (63\%), Akpodiete et al. (1997) (54.3\%) Awoniyi et al. (2003) (55.1\%), Sogbesan et al. (2006) (55.4\%), Hwangbo et al. (2009) (63.99\%) and Odesanya et al. $(2011)(48.0 \%)$. 
472

The crude fibre recorded in the present study $(3.0 \%)$ was slightly similar with that reported by Omoyinmi and Olaoye (2012) (2.41\%), but clearly at variance with those of Ugwumba et al. (2001) (9.5\%), Sogbesan et al. (2006) (1.56\%), Aniebo et al. (2009) (7.5\%), Odesanya et al. (2011) (5.89\%) and Abraham et al. (2015) (5.54\%). The differences in the nutrient component can be as a result of differences in processing method (Fasakin et al., 2003), differences in age at harvest (Calvert et al., 1970; Inaoka et al., 1999; Newton et al., 2004; Aniebo and Owen 2010; Ukanwoko and Olalekan, 2015), method of drying (Fasakin et al., 2003; Aniebo and Owen, 2010) and larval feed substrate (Newton et al., 1977; Abraham et al., 2015). The age of the maggots was not known, however, poultry dung used for the production of the maggots in the present study has been reported to be the best substrate for maggot production (Anene et al., 2013).

The economic evaluation of feeding $C$. gariepinus fingerlings on experimental diets showed that $60 \%$ maggot meal-based diet recorded the highest net gain and cost benefit ratio.

The positive net gain and cost benefit ratio recorded in all the diets indicates that $C$. gariepinus can be economically reared on all diets. This is in agreement with Sogbesan et al. (2006) who reported that maggot meal can economically substitute fish meal up to $50 \%$ in the diet of Heteroclarias. Previous reports have shown that maggots are suitable for partial replacement of fish meal in mud catfish diets (Sogbesan et. al., 2005; Olaniyi ans Salau 2013; Samuel and Nyambi, 2013; Michael and Sogbesan, 2015). However, the cost of production and the benefits positively favored all treatment since the values calculated are $>1.0$ which shows an increase in the fish value above the amount invested.

The proximate composition of $C$. gariepinus carcass before and after experiment showed an increase in crude protein content at the end of the experiment. This indicates that fish were able to utilize the protein in the feed and convert it to body growth.

The progressive growth of experimental fish indicates efficient usage of feed. The study is in accordance with other studies which have observed a better growth performance of fish fed diets containing maggot meal over those fed on fish meal-based diets (Ogunji et al., 2006; Adenugba, 2012). This is indicating that the replacement of fish meal with maggot meal up to $70 \%$ inclusion level is suitable for optimal growth performance of $C$. gariepinus fingerlings, which is in agreement with the work of Adenugba (2012), Akinwande et al. (2002), Dada and Akinwande (2005), Sogbesan et al. (2005) and Ajonina and Nyambi (2013). The results from the present study are in accordance with previous observation that maggot meal, like other animal protein sources, is well accepted and utilized by fish (Alegbeleye et al., 1991; Adenugba, 2012; Idowu et al., 2003).

The lowest food conversion ratio in fish fed 60\% maggot meal diet indicates that they were most efficient in converting their food. Even the lowest growth performance in the control diet could be due to their highest food conversion ratio as compared to other fish fed with maggot meal diet, indicating that fingerlings on the control diet were least efficient in conversion of their food.
The highest specific growth rate and relative growth rate were obtained in fish fed with the $60 \%$ maggot meal diet. This could be due to the fact that food conversion efficiency was best in fingerlings in this diet regime. This is contrary to the reports by Akinwande et al. (2002) and Adenugba (2012) who reported best growth of $C$. gariepinus fingerlings at $70 \%$ and $75 \%$ maggot-based diets respectively. Protein is the nutrient that is required in the largest quantity for growth and development of fishes, but also the most expensive ingredient in diet formulation (Lovell, 1989). Thus, protein intake of the experimental fish indicates that protein in the feed was efficiently utilized, which was reflected in the final carcass of the experimental fishes as there was considerable increase in the crude protein of the final carcass.

The ability of an organism to utilize nutrients, especially protein, will positively influence its growth rate (Sogbesan and Ugwumba, 2008). Jhingram (1983) reported that maggots are easily digested by fish, which is justified by the highest protein efficiency ratio in all the experimental fish diets. This suggests that the fish must have efficiently converted feed consumed to growth. A high protein efficiency ratio value is indicative of good protein digestibility and bioavailability for optimum body protein increase and growth (Pellett et al., 1989).

Value of physico-chemical parameters of water monitored during the experimental period were within the suitable range for tropical fish (Adigun, 2005)). This implies that the environmental conditions during the experimental period were suitable and adequate for fish culture. This could also have contributed to the high rate of survival of the experimental fish.

\section{Conclusions}

The lowest food conversion ratio in fish fed 60\% maggot meal diet indicates that they were the most efficient in converting their food. The highest specific growth rate and relative growth rate were also obtained in fish fed with the $60 \%$ maggots of Musca domestica diet, thus such a diet can be recommended for optimal growth performance and nutrient utilization. Survival rate was generally high in all the diets implying that maggot meal enhanced survival of fish during culture and this indicates the suitability of maggots in the diet of $C$. gariepinus fingerlings.

\section{References}

A.O.A.C. (Association of Official Analytical Chemists) International. (2012). Official Methods of Analysis of AOAC International, 19th Edition. Gaithersburg Maryland, USA, AOAC International pp 1230.

Abraham KO, Richard AA, Samuel A (2015). Proximate composition of housefly (Musca domestica) maggots cultured on different substrates as potential feed for Tilapia(Oreochromisniloticus). International Journal of Multidisciplinary Research and Development 2(5):102-103.

Adenugba TO (2012). Production of maggots from aluminium mobile maggotry, aluminium, plastic and wooden boxes and their utilization in 'Heteroclarias'diet. MSc. Project, Unpublished, Department of Zoology, University of Ibadan, Nigeria. 
Adigun BA (2005). Water quality management in aquaculture and freshwater zooplankton production for use in fish hatchery. National Institute for Freshwater Fisheries Research, New Bussa, Niger State.

Agbabiaka LA, Amadi AS, Madubuko CU, Nwankwo FC, Ojukannaiye AS (2012). Assessment of nutrients and sensory qualities of brine pretreated catfish smoked with two different woods. African Journal of Food Science 6(9):245-248.

Ajonina AS, Nyambi RE (2013). Evaluation of growth response of Clarias gariepinus fingerling feddried maggot as protein source. International Journal Current Microbiology and Applied Science 2(5):123-129.

Akinwande AA, Ugwumba AAA, Ugwumba OA (2002). Effect of replacement of fish meal with maggot meal in the diet of Clarias gariepinus (Burchell, 1822) fingerlings. The Zoologist 1(2):41-46.

Akpodiete OJ, Ologhobo AD, Oluyemi JA (1997). Production and nutritive value of housefly maggot meal on three substrates of poultry faeces.Journal of Applied Animal Research 12(1):101-106.

Alegbeleye WO, Anyanwu DF, Akeem AM (1991). Effect of varying dietary protein levels on the growth and utilization performance of catfish, Clarias gariepinus. Proceedings of the $4^{\text {th }}$ Annual Conference of Nigerian Association of Aquatic Science Ibadan, Nigeria pp 51-53.

Anene A, Afam-Anene OC, Ike K, Ekekwe NH (2013). Preliminary investigations on quantity of maggots produced from four different sources of livestock wastes. Journal of Research in Biology 3(6):1060 1065.

Aniebo AO, Erondu ES, Owen OJ (2009). Replacement of fish meal with maggot meal in African catfish (Clarias gariepinus) diets. Revista UDO Agricola 9(3):666-671.

Aniebo AO, Owen OJ (2010). Effects of age and method of drying on the proximate composition of houseflylarvae (Musca domestica linnaeus) meal (HFLM). Pakistan Journal of Nutrition 9(5):485-487.

Atteh JO, Olegbenla FD (1993). Replacement of fishmeal with maggots in broiler diet: Effects on performance and nutrient retention. Nigerian Journal of Animal Production 20(1):44-49.

Awoniyi TAM, Aletor VA, Aina JM (2003). Performance of broiler chickens fed on maggot meal in place of fishmeal. International Journal ofPoultryScience 2(4):271-274.

Bene C, Heck S (2002). Fisheries and the millennium development goals: Solution for Africa. Naga, Worldfish Center Quarterly 28(3-4):14-18.

Boyd CE (1990). Water quality in ponds for aquaculture. Alabama Agriculture Experiment Station, Auburn University, Alabama pp 462.

Calvert CC, Martin RD, Morgan NO (1970). House flies pupae as food for poultry.Journal Economic Entomology 62(4).

Calvert CL (1976). Systems for indirect recycling by using animal and municipal wastes as a substrate for protein production. Chapter 8. In. Feed Resources Proceedings of Technical Consultation, FAO.

Dada AA, Akinwande AA (2005).Growth performance of Heteroclarias fed maggot meal at varying Inclusion levels. 2004 Fisheries Society of Nigeria (FISON) Conference Proceedings pp 896.

Ezewudo BI, Monebi CO, Ugwumba AAA (2015). Production and utilization of Musca domestica maggots in the diet of Oreochromis niloticus (Linnaeus, 1758) fingerlings. African Journal of Agricultural Research 10(23):2363-2371.

FAO(2012). State of the world fisheries. Rome.
FAO (2006). Nigeria's fisheries profile. Retrieved on 2006 February 2 from www.fao.org/fi/fcp/en/NGA.

Fasakin EA, Balogun AM, Ajayi OO (2003). Evaluation of full fat and defatted maggot meals in the feeding of clariid catfish Calarias gariepinus fingerlings. Aquaculture Research 34(9):733-738.

Federal Department of Fisheries (FDF) (2007). Fisheries statistics of Nigeria. $4^{\text {th }}$ Edition 1995-2007 pp 49.

Gado MS, El-Aggory SM, Elgawaad AA, Mahmoud AK (1982). The possibility of applying insect protein in broiler rations. Research BulletinAin-Shams University.

Hwangbo J, Hong EC, Jang A, Kang HK, Oh JS, Kim BW, Park BS (2009). Utilization of house fly-maggots, a feed supplement in the production of broiler chickens. Journal of Environmental Biology 30(4):609-614.

Idowu AB, Amusan AAS, Oyediran AG (2003). The response of $C$. gariepinus (Burchell, 1822) to the diet containing housefly maggot, (Musca domestica). Nigerian Journal of Animal Production 30(1):139144 .

Inaoka T, Okubo G, Yokota M, Takemasa M (1999). Nutritive value of house fly larvae and pupae fed on chicken faeces as food source for poultry.Japanese Poultry Science 36(3):174-180.

Jhingram VG (1983). Fish and fishes of India ( $\left.2^{\text {nd }} e d\right)$. Hindustan Publishing Corporation, Delhipp 727.

Lovell T (1989). Nutrition and feeding of fish. Van Nostrand Reinhold, NY, USA, pp 240.

Michael KG, Sogbesan OA (2015). Evaluation of maggot meal (Musca domestica) and single cell protein (mushroom) in the diet of Clarias gariepinus fingerlings (Burchell, 1822). Fisheries and Aquaculture Journal 6(3):1-5.

Monebi CO, Ugwumba AAA (2013). Utilization of the earthworm (Eudrilus engeniae) in the diet of heteroclarias fingerlings. International Journal of Fisheries and Aquaculture 5(2):19-25.

Newton GL, Booram CV, Barker RW, Hale OM (1977). Dried Hermetia illucens larvae meal as a supplement for swine. Journal of Animal Science 44(3):395-400.

Newton L, Sheppard C, Watson D, Burtle G, Dove R (2004).Using the black soldier fly, Hermetia illucens, as a value-added tool for the management of swine manure. Animal and Poultry Waste Management Center, North Carolina State University, Raleigh, NC, 17.

Odesanya BO, Ajayi SO, Agbaogun BKO, Okuneye A (2011). Comparative evaluation of nutritive value of maggots. International Journal of EngineeringScience 2(11):1-5.

Ogunji JO, Kloas W, Wirth M, Schulz C, Rennert B (2006). Housefly maggot meal (Magmeal): An emerging substitute of fishmeal in Tilapia diets. Proceedings of Conference on International Agronomy Research for Development, Stuttgart-Hohenheim, October 11-13, pp 1-7.

Ogunji J, Slawski H, Schulz C, Werner C, Wirth M (2008). Preliminary evaluation of housefly maggot meal as an alternative protein source in diet of carp (Cyprinus carpio L.). World Aquaculture Society.

Okah U, Onwujiariri EB (2012). Performance of finisher broiler chickens fed maggot meal as a replacement for fish meal. Journal of Agricultural Science and Technology 8(2):471-477. 
474

Olaniyi CO, Salau BR(2013). Utilization of maggot meal in the nutrition of African cat fish. African Journal of Agricultural Research 8(37):4604 4607.

Olomola A (1990). Capture fisheries and aquaculture in Nigeria: A comparative economic analysis. Africa Rural Social Science Series Report,No. 13, Ibadan, Nigeria, University Press Ltd.

Omoyinmi GAK, Fagade SO, Adebisi AA (2005). Assessment of different organic substrates in the laboratory culture of some live food organisms. Zoologist 3:105-111.

Pellett P (1989). Report of a joint FAO/WHO expert consultation on protein quality evaluation. Bethesda, M.D., U.S.A, 48 December. FAO and Food Nutrition Paper,pp 51-72.

Samuel AA, Nyambi RE (2013). Evaluation of growth response of Clarias gariepinus fingerling fed dried maggot as protein source. International Journal Current Microbiology and Applied Science 2(5):123-129

Sogbesan OA, Ugwumba AAA (2008). Nutritional evaluation of termite (Macrotermes subhyalinus) meal as animal protein supplements in the diets of Heterobranchus longifilis (Valenciennes, 1840) fingerlings. Turkish Journal of Fisheries and Aquatic Sciences 8(1):149-157.

Sogbesan AO, Ajuonu N, Musa BO, Adewole AM (2006). Harvesting techniques and evaluation of maggot meal as animal protein source for 'Heterobranchus' in outdoor concrete tanks. World Journal of Agricultural Sciences 2(4):394-402.
Sogbesan OA, Ajuonu ND, Ugwumba AAA, Madu CT (2005). Cost benefits of maggot meal as supplemented feed in the diets of Heterobranchu slongifilis $\mathrm{x}$ Clarias gariepinus (Pisces-Clariidae) hybrid fingerlings in outdoor concrete tanks. Journal of Industrial and Scientific Research 3(2):51-55.

Ugwumba AAA, Abumoye OO (1998). Growth response of Clarias gariepinus fingerlings fed live maggot from poultry droppings. In: Sustainable Utilization of Aquatic/Wetland Resources. Selected papers from $9^{\text {th }} / 10^{\text {th }}$ Annual Conference of the Nigerian Association for Aquatic Sciences, Abeokuta, Nigeria, 30 ${ }^{\text {th }}$ Nov-2 ${ }^{\text {nd }}$ December, pp 60-68.

Ugwumba AAA, Ugwumba OA, Okunola AO (2001). Utilization of live maggot as supplementary feed on the growth of Clarias gariepinus (Burchell) fingerlings. Nigerian Journal of Science 35(1):1-7.

Ukanwoko AI, Olalekan OA (2015). Effects of source and time of harvest on the proximate composition of maggot (Musca domestica) larva meal. International Journal ofLivestock Research 5(7):84-90. 